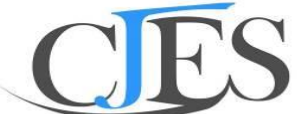

Cypriot Joumal of Educational Sciences

\title{
Play skill levels and toy preferences of disabled children according to their mothers
}

Rukiye Konuk Er ${ }^{a^{*},}$ Necmettin Erbakan University, Ahmet Keleşoğlu Education Faculty, Special Education Department, konya, Turkey https://orcid.org/0000-0002-9500-0534

Şenay ilik ${ }^{b}$, Necmettin Erbakan University, Ahmet Keleşoğlu Education Faculty, Special Education Department, konya, Turkey 05065134709, https://orcid.org/0000-0001-7092-379X

\section{Suggested Citation:}

Konuk Er, R., \& ilik, Ş. (2022). Play skill levels and toy preferences of disabled children according to their mothers. Cypriot Journal of Educational Science. 17(2), 384-395 https://doi.org/10.18844/cjes.v17i2.6821

Received from November 20, 2021; revised from December 14, 2021, accepted from February 22, 2022

${ }^{\circ} 2022$ Birlesik Dunya Yenilik Arastirma ve Yayincilik Merkezi. All rights reserved.

\begin{abstract}
This study aims to examine the views of mothers regarding plays and toys which are of great significance also for children with intellectual retardation and learning disability. This study was conducted through a mixed method by using qualitative and quantitative methods together. Seventy-five mothers who participated in the study were chosen by using the purposive sampling method in the first stage and the random sampling method in the second stage. Data were collected through the 'Play Skills Scale' and 'Mother Interview Form'. The quantitative data were analysed through Mann-Whitney $U$ and KruskalWallis $\mathrm{H}$ tests and qualitative data were analysed through content analysis. In the qualitative dimension of the study following themes were found; playing with the child, the toys the child plays with, whether the child has a toy he/she always plays with, and whether giving the child the right to choose when buying toys. For the quantitative dimension of the study significant difference was found between the play skill levels, disability type, giving the child the right to choose when buying toys, and toy type variables.
\end{abstract}

Keywords: Early childhood; intellectual retardation; learning disability; play; toy.

\footnotetext{
* ADDRESS OF CORRESPONDENCE: Rukiye Konuk Er, Necmettin Erbakan University, Ahmet Keleşoğlu Education Faculty, Special Education Department, konya, Turkey

Email address: rukiyekonuk@gamil.com / Tel: +905054963325
} 


\section{Introduction}

Play which exists everywhere humans exist is a universal concept and 'play is a part of real-life and the most efficient learning process which has a purpose or not, which has certain rules or not, which children perform willingly and which is the basis of physical, cognitive, linguistic, emotional and social development' (Aral et al., 2001; Sezgin, 2016). Play which supports positively all the developmental areas of children and which plays an important role in gaining skills is a universal language among children (Brodin, 1999; Cakmak \& Elibol, 2015; Tugrul, 2015).

Play varies according to the development of children. Plays can be grouped according to their structure, the place they are played, the use of tools, the material they are played with, and physical plays and plays with music (Ozturk, 2010). Materials used in plays and known as toys are the very basic tools for learning, and development from the beginning of a child's life (Adak-Ozdemir \& Ramazan, 2012; Bianquin, 2018). Plays and toys are occupations that provide many developmental gains to children (Avci, 2002; Yaman, 2019).

Children with special needs can improve their cognitive skills along with their social skills with plays (Bianquin, 2018; MEB, 2014). Several studies have revealed that plays support many developmental areas such as attention, sharing and cooperation, hand-eye coordination, movement skills, and coping skills in children having different disabilities such as intellectual retardation (IR), learning disabilities (LD), physical disabilities, and autism (Ayan et al., 2012; Aydin Yesilyurt, 2019; Bedir Eristi et al., 2017; Pouya et al., 2017; Stagnitti, 2014; Tsai \& Lin, 2011).

Children with special needs can have difficulty playing with a toy. While it varies according to the level retardation, it is generally revealed in the studies that these children have trouble in combining and forming objects during the play (Karaca Ciftci \& Aydin, 2017; Movahedazarhouligh, 2018; Nelson et al., 2007; Papacek et al., 2016). In the study they conducted on children with LD, Demirci and Toptas Demirci (2016) found that these children have problems in psycho-motor abilities and playing toys such as jigsaw puzzles, toy blocks, and cubes. Similar difficulties can be seen within the children with IR. These children have problems such as playing with younger children, choosing activities they know, restricted communication with their peers, and playing aimlessly with toys (Bianquin, 2018; Bulgarelli, 2020).

When the studies in the literature examined, studies regarding how the play skills performed by each child changes in the children with special needs can be found (Besio, 2018; Buysse et al., 2002; Karaca Ciftci \& Aydin, 2017; Pistav Akmese \& Kayhan, 2017). While some of these studies aimed to investigate the effects of plays directly with the participation of the child (Alotibi \& Algahtani, 2019; Boyraz, 2017; Demirci \& Toptas Demirci, 2016) some other studies tried to determine the development of children through their parents' views (Stillianesis et al., 2021). On the other hand, there exist studies conducted with special education teachers and prospective teachers (Eren, 2018; Pistav Akmese \& Kayhan, 2017; Yikmis et al., 2017).

Stillianesis et al. (2021) investigated the ways of parents' risk management during their plays with their children. Parents indicated that they have fears during the plays regarding the safety of their children. Venuti et al.'s (2009) study revealed that mothers of children with IR joined the game or directed the game according to the needs of their children. Alotibi and Algahtani (2019) investigated the effects of play on the quality of life and found out that play contributes to the quality of life. Demirci and Toptas Demirci (2016) investigated the gains that children with special needs obtained during their game and physical activities classes. Their findings revealed that although there exist certain limitations when their gains are considered using play to teach certain points is necessary. In Case-Smith and Kuhaneck's (2008) study with the participation of children with special needs, they found out that different game types and children's preferences regarding toys are effective in reaching the objectives.

Play activities help develop social interaction skills and help people with disabilities be accepted by their typically developing peers. It also helps to increase strength and social communication, develop 
self-confidence, raise their mood, and educate them on socially acceptable behaviours, responsibilities, and social roles. In situations where play is so important, the studies on play are important.

It is considered that our study will contribute to the studies conducted in the field by obtaining mothers' observations of their children and determining their views on this issue. This study aimed to examine the play skills and toy choices of children with IR and LD through the views of their mothers.

With this purpose in mind, answers to the following questions were sought in this study.

1. What are the mothers' views on toy selection and their ability to play games together?

-What are the games played with the child?

- What are the toys that the child plays alone?

- Does the child have a toy that he always plays with?

- Is the child given the right to choose his/her toys?

2. Regarding children's game skills;

- Does it vary by the type of disability?

- Does it vary depending on whether the child is given the right to choose the toys?

- Does it vary depending on the type of toy he/she chooses?

\section{Method}

\subsection{Research design}

In this study, a mixed method design, in which qualitative and quantitative research techniques are used together, was adopted. When there is a need for in-depth knowledge in educational sciences and social science research, mixed method design can be preferred in order to benefit both quantitative and qualitative data (Creswell et al., 2003).

\subsection{Participants of the study}

The purposive sampling method, which is one of the non-random sampling methods, was used to determine the research group. The reason why the purposeful sampling method is preferred is to obtain deeper and more detailed information about the children's playing skills and the toys they prefer, how and with whom they play together, and what objects they use to play according to the views of the mothers of the children with special education needs (Buyukozturk, 2005). The study was conducted with mothers who had a child with special education needs and who declared that they wanted to participate voluntarily in the study.

The mothers were respectively distributed as follows based on their ages; $18.7 \%, 33.3 \%, 32 \%$, and $16 \%$ of the participants were between the ages of $30-35,36-40,40-45,46$, and more. When the number of children in the families was examined, it is found that $10.7 \%$ of the families have one child, $38.7 \%$ of the families have two children, $28 \%$ of them have three children, $17.3 \%$ of them have four children, and $5.3 \%$ of them have five or more children. When the demographic qualifications of the children are examined, it is seen that $46.7 \%$ of them have an LD ( 35 children), $53.3 \%$ of them have mild IR (40 children). $32 \%$ of the children are female and $68 \%$ of them are males.

\subsection{Data collection tools}

\subsubsection{Parent interview form}

First of all, to develop the parent interview form, a draft form was prepared by examining the related literature (Besio, 2018; Buysse et al., 2002; Pistav Akmese \& Kayhan, 2017). Play skills of children with special needs, the toys they play with, and parents' knowledge and skill level regarding plays are 
primarily searched in the literature. A semi-structured interview form containing six questions was developed to find out the views and skills of mothers with children with special needs regarding plays. In the second step, reminders and explanatory statements were developed for the questions needing explanation. In the third step, to ensure validity, the form was examined by three academicians (two child development and one special education specialist) working in Necmettin Erbakan University Ahmet Kelesoglu Education Faculty. The interview form was edited and the number of questions was decreased to four. In the fourth step, some statements were rearranged after conducting a pilot study with five mothers. In the last step, by considering the results of the pilot implementations and other reviews, the interview form was made ready for implementation.

\subsubsection{Play Skills Scale}

Play Skills Scale was developed by Fazlioglu et al. (2013) to identify the play skills of children. The sample group of the study consisted of 243 parents having children who are 60-72 months old. The scale has one dimension and explains $35.16 \%$ of the total variance. CFA (Confirmatory Factor Analysis) was conducted to test the single dimension structure. Results showed a satisfactory consistency for the model. The standardised regression coefficient of the scale was found between 0.42 and 0.75 and these results were found statistically significant. Internal consistency reliability Cronbach's alpha coefficient was found as 0.93 .

\subsection{Data collection}

Interviews were conducted on a volunteer basis. An explanation regarding the aim and method of the study was prepared for the interviews. Furthermore, it is emphasised that the identity of the participants will be kept anonymous. Implementation was done through written forms applied by researchers who are experts in special education and child development. Interviews lasted for 20-25 minutes.

\subsection{Data analysis and interpretation}

Statistical analysis was conducted by taking into consideration the collection of qualitative and quantitative data (Butgel Tunali et al., 2016; Yildirim \& Simsek, 2005). In the qualitative dimension of the study, the collected data were analysed through descriptive analysis. When starting the descriptive analysis, a framework for data analysis was created based on the research questions and the dimensions included in the interview. The researchers examined the interview forms by creating a checklist for coding for each item. The checklist was first created independently by the researchers, then the researchers came together to finalise. The data were first analysed independently based on the checklist by the researchers, then the codes were compared and to secure the reliability of the study, the Consensus/Agreement + Disagreement Formula was used to calculate the reliability for all questions and it was found as $80 \%$. As a result of the opinions obtained for this research and considering the relevant literature, the themes of games played with the child, toys played by the child alone, whether the child has a toy that he/she plays always and giving the child the right to choose the toys were determined. These themes were grouped into sub-categories. The participating mothers' views on these categories were included (Coolican, 1992).

Mann-Whitney $U$-test and Kruskal-Wallis $H$ test were used for statistical analysis of quantitative data.

During the study, ethical and moral principles were strictly followed in all stages of data collection and interpretation/analysis.

\section{Findings}

\subsection{Qualitative findings regarding views of mother about their shills of playing with their children and} the toys children have

As a result of the mothers' views following four themes were determined; playing with the child, the toys the child plays with, whether the child has a toy he/she always plays with, and whether he/she 
has a right to choose when buying toys. Then, these four themes were separated into sub-categories. Views regarding each category were given. Table 1 shows the themes, sub-categories, number of mothers expressing views about each category and sample views. The disability types of the children are stated as LD/IR abbreviation. In addition, mothers were coded using pseudonyms such as Mother 1 (M1). The answers of the mothers were not limited to one category and were included in more than one category.

Table 1. Views of mothers on their children's playing skills and toys

\begin{tabular}{ll}
\hline Themes Categories & $\begin{array}{l}\text { Number of Views of mothers } \\
\text { mothers } \\
\text { (LD/IR) }\end{array}$
\end{tabular}

\begin{tabular}{|c|c|c|c|}
\hline \multirow{9}{*}{ 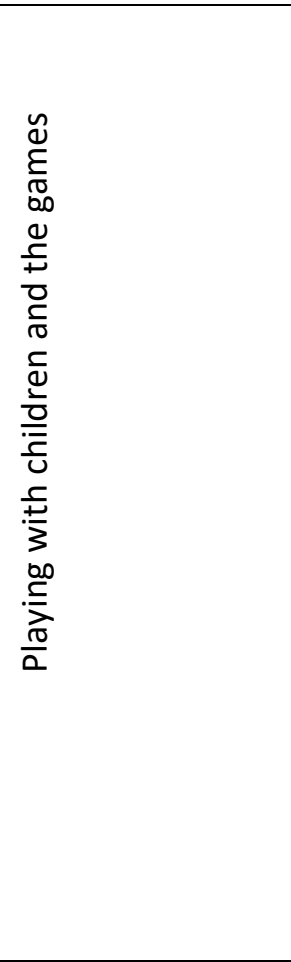 } & \multirow{6}{*}{$\begin{array}{l}\text { Plays with toys } \\
\text { Plays without toys }\end{array}$} & \multicolumn{2}{|r|}{ 'we play with ball' (A65) } \\
\hline & & $15 / 24$ & $\begin{array}{l}\text { 'we play hiding/seeking objects/toys' } \\
\text { (M59) }\end{array}$ \\
\hline & & & 'we playing house' (17) \\
\hline & & $14 / 10$ & $\begin{array}{l}\text { 'we sing together, we imitate the activities } \\
\text { she learned at school' (M66) }\end{array}$ \\
\hline & & & $\begin{array}{l}\text { 'we play blind man's buff and hide and } \\
\text { seek' (M33) }\end{array}$ \\
\hline & & & 'we do jigsaw puzzles' (M68) \\
\hline & Mind games & $15 / 7$ & $\begin{array}{l}\text { 'we play finding cities on the map and do } \\
\text { jigsaw puzzles' (M22) }\end{array}$ \\
\hline & $\begin{array}{l}\text { Technological } \\
\text { games }\end{array}$ & $16 / 4$ & 'child games on the phones' (M60) \\
\hline & $\begin{array}{l}\text { Not playing } \\
\text { games }\end{array}$ & $6 / 18$ & $\begin{array}{l}\text { 'He is playing PC games, and I think playing } \\
\text { games is childish' (M45) }\end{array}$ \\
\hline & $\begin{array}{l}\text { Toys for playing } \\
\text { house }\end{array}$ & $11 / 12$ & 'play house, plays with dolls' (M57) \\
\hline & & & 'plays with dolls and kitchen tools' (M32) \\
\hline & $\begin{array}{l}\text { Mind developing } \\
\text { toys }\end{array}$ & $18 / 16$ & 'plays with toy blocks' (M69) \\
\hline$\frac{5}{3}$ & $\begin{array}{l}\text { Toys such as } \\
\text { cars/dolls }\end{array}$ & $21 / 15$ & $\begin{array}{l}\text { 'plays with babies for hours by making } \\
\text { them talk' (A27) }\end{array}$ \\
\hline $\begin{array}{l}\frac{\pi}{0} \\
\frac{\pi}{2} \\
\underline{\underline{0}}\end{array}$ & & & $\begin{array}{l}\text { 'loves playing with cars and lorries, also } \\
\text { plays with models' (M52) }\end{array}$ \\
\hline 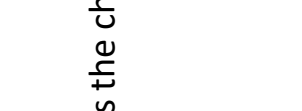 & Technological and & $21 / 12$ & $\begin{array}{l}\text { 'loves playing with phone the most but } \\
\text { also rides bicycle' (M44) }\end{array}$ \\
\hline $\begin{array}{l}\text { Dे } \\
\stackrel{0}{ \pm} \\
\stackrel{F}{F}\end{array}$ & noisy toys & & $\begin{array}{l}\text { 'doesn't spend much time with toys but } \\
\text { noisy toys attracts her attention' (M8) }\end{array}$ \\
\hline 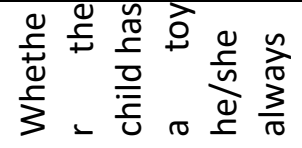 & Yes & $13 / 21$ & $\begin{array}{l}\text { 'loves doing jigsaw puzzles' (M62) } \\
\text { 'loves playing with speaking dolls' (M57) }\end{array}$ \\
\hline
\end{tabular}


'doesn't have many toys he likes, plays

No $\quad 32 / 19$

with what I give him' (M45)

'No, she doesn't have' (M12)

\begin{tabular}{|c|c|c|c|}
\hline \multirow{4}{*}{ 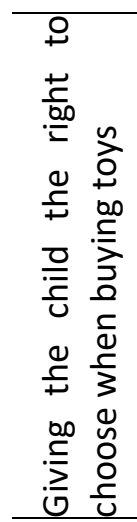 } & \multirow{2}{*}{ Always } & \multirow{2}{*}{$18 / 6$} & \multirow{2}{*}{$\begin{array}{l}\text { 'I give him the right to choose toys, I don't } \\
\text { force him' (A64) } \\
\text { 'he chooses by himself, I sometimes make } \\
\text { suggestions' (M31) }\end{array}$} \\
\hline & & & \\
\hline & Sometimes & $7 / 9$ & $\begin{array}{l}\text { 'generally we choose but sometimes she } \\
\text { does' (M44) }\end{array}$ \\
\hline & Never & $10 / 25$ & $\begin{array}{l}\text { 'she doesn't know how to choose herself, } \\
\text { so I choose toys that can be useful to her' } \\
\text { (A18) }\end{array}$ \\
\hline
\end{tabular}

\subsubsection{Games played with the children}

Out of 75 mothers participating in study 24 of them stated that they do not play with their children. Six of the mothers who do not play games are mothers of LD and 18 of them are IR. Playing with the child theme consist of four categories. The category of 'games played with toys' was repeated 39 times and 15/24 (LD/IR) was stated by the mother. The mothers expressed their opinions in the categories of 'games played without toys' 14/10 (LD/IR), 'mind games' 15/7 (LD/ IR), and 'technological games' $16 / 4$ (LD/IR).

\subsubsection{The toys the child plays alone}

This theme is composed of four categories. Out of 75 mothers who participated in the study, 11/12 (LD/IR) of them reported 'toys for playing house', 18/16 (LD/IR) of them answered the question as 'mind games', 21/15 (LD/IR) of them reported 'personal toys such as cars/dolls' toys' and 21/12(LD/IR) reported 'technological toys' categories.

\subsubsection{Whether having a toy he/she always plays with}

The theme of whether having a toy he/she always plays is composed of two categories. Among the 75 mothers who participated in the study, 13/11 (LD/IR) mothers expressed their opinion in the 'yes', and $32 / 19$ (LD/IR) of them in the 'no' categories.

\subsubsection{Giving the child the right to choose when buying toys}

This theme is composed of three categories. Out of the 75 mothers who participated in the study, 18/6 (LD/IR) of the mothers shared their opinions in the 'always' category, 7/9 (LD/IR) of them in the 'sometimes' category while 10/25 (LD/IR) of the mothers in the 'never' categories.

\subsection{Quantitative findings examining the play skill level of children according to views of mothers}

Table 2. Choosing toys suitable for disability type

\begin{tabular}{|c|c|c|c|c|c|c|}
\hline & Disability type & $N$ & Mean & SE & $U$ & $p$ \\
\hline$=$ & LD & 35 & 109.88 & 2.63 & & \\
\hline 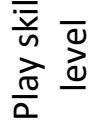 & $\mathrm{IR}$ & 40 & 88.60 & 3.44 & $\begin{array}{l}294.0 \\
0\end{array}$ & 0.00 \\
\hline
\end{tabular}

$p<0.05$. 
Table 2 reveals the data examining the relationship between toy choice and disability type. The data collected from the mothers having children with special needs were analysed through Mann-Whitney Test and a significant difference was found.

Table 3. Giving the child the right to choose when buying toys

\begin{tabular}{|c|c|c|c|c|c|c|}
\hline & The right to choose toys & $N$ & Mean & SD & $x^{2}$ & $p$ \\
\hline \multirow{3}{*}{ 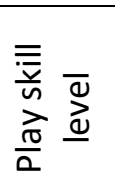 } & Always & 14 & 79.92 & \multirow{3}{*}{2} & \multirow{3}{*}{16.41} & \multirow{3}{*}{0.00} \\
\hline & Sometimes & 11 & 89.27 & & & \\
\hline & Never & 50 & 105.78 & & & \\
\hline
\end{tabular}

$p<0.05$.

In Table 3, the relationship between play skill levels of children with special needs and their right to choose their toys was examined through Kruskal-Wallis Test and a significant difference was found.

Table 4. Choosing toys considering toy type

\begin{tabular}{cllllll}
\hline & The toy type & $N$ & Mean & SD & $X^{2}$ & $p$ \\
\hline $\begin{array}{c}\text { Play skill } \\
\text { levels }\end{array}$ & Toys for playing house & 30 & 96.20 & & & \\
& Mind developing toys & 8 & 111.12 & & & \\
& Toys like cars & 31 & 99.51 & 3 & 7.91 & 0.04 \\
& Noisy toys & 3 & 77.66 & & \\
& Others & 3 & 99.00 & & \\
\hline
\end{tabular}

$p<0.05$.

Table 4, in line with the views collected from mothers, shows the relationship between the play skill level of children with special needs and choosing toys considering toy type. The data were analysed using Kruskal-Wallis test and a significant difference was found.

\section{Discussion, conclusion, and implications}

Play gives the child the chance of self-experiencing the things no one else cannot teach. Play is an activity that offers education and entertainment to the child at the same time (Wong \& Kasari, 2012). Play activities increase the formation of normal behavioural tendencies through the interaction and integration of emotions (Aykara, 2017; Zaatar, 2003).

In this study, it was aimed to determine the play/toy preferences and play skills levels of children with LD and IR from their mothers. In line with the qualitative data, children's toy selection and their ability to play together were determined, and the themes of the games played with the child, the toys that the child plays alone, whether the child has a toy that he always plays with, and whether the child is given the right to choose a toy or not have been obtained. Based on the quantitative data obtained from the mothers, it was determined that there was a significant difference in the play skills of the children, according to the type of disability, the situation of giving the child the right to choose a toy, and the type of toy they chose varied.

The views of mothers about their children's plays were evaluated with four questions. The first of these was about mothers playing games with their children. In this theme, it was determined that mothers played games with toys, games played without toys, mind games, and technological games they played with their children. 24 out of 75 mothers who participated in the study stated that they did not play with their children. The fact that the majority of mothers who do not play games consist of the ones who are the mothers of the children with IR suggests that mothers need the knowledge regarding how to play games with their children. 
The views of mothers who avoid playing games with their children that playing games are childish may indicate that they still need support about the importance of play and that they evaluate the situation they are indifferent. According to Mahoney et al. (1999), play does not mean the same thing for children with and without disabilities. The game shows some similarities and some differences in terms of children with and without disabilities. The most fundamental difference is that most adults take part in the games of children with special needs and their guidance is needed.

At this point, it can be stated that the vast majority of mothers were willing to play. It is of great importance that the individuals around the child are equipped and willing for play activities that offer both fun, evaluation, and development of the learning skills at the same time. When it comes to children with special needs, mothers need to acquire new skills about their existing play skills.

It was determined that all of the children played alone with one or more toys. Categories have been determined for these toys, and these categories are house toys for games that include playmaking, toys that develop intelligence, toys such as cars/dolls, and toys with sound. According to the results obtained, it was determined that the majority of children play personal toys such as dolls/cars. Among the games played, it was observed that there were the least number of toys for playmaking games, and it was determined that this situation was more common among the children with IR. Based on this, it can be said that children with LD and IR have difficulties in playmaking.

Considering another qualitative finding, whether the child has a toy that they always play, it is noteworthy that the majority of children with both IR and LD do not have toys that they always play with. In this context, providing children with guidance and spending time with their toys is very important for children's character development, gender development, happiness, and feeling safe (Adak Ozdemir \& Ramazan, 2012; Bekmezci \& Ozkan, 2015; Lenakakis et al., 2018; Yalcinkaya, 2005). Considering the results regarding mothers' giving the right to choose when buying new toys, it was found that the rate of mothers who considers the preference of children was high among the mothers who have children with LD. In addition, it was concluded that the majority of mothers of children with IR did not give their children the right to choose for various reasons. It has been determined that the mothers of children with IR are worried that the toys their children will choose will not benefit the child mentally or physically.

It was determined that there was a significant difference in terms of children's play skill levels and types of disabilities. This result is also in line with the qualitative findings of our study. Among the qualitative findings, there are findings that are not similar between LD and IR in many categories. Different results have emerged depending on the type of disability in many categories such as games played with the mother, mind games, technological games, and playmaking.

In line with the information given by mothers of children with special educational needs, the relationship between children's play skill levels and their right to choose toys was examined and a significant difference was found. Both the right to choose toys in the qualitative play skill and the findings of giving the right to choose a toy in our qualitative findings support each other. Because it is observed that the limits of the children's right to choose vary depending on both the type of disability and the type of toy. It can be said that these variations in the right to choose given to the children while buying a toy are because of the need for guidance and also the consideration of the special needs of the children and the different toy preferences that will support their development. Because the toys and play types provided considering their developmental characteristics contribute to the benefit of parents and their children more. Studies in the literature support this finding. Kim et al.'s (2003) findings revealed that the social skills of children playing with social toys that required group activity were increased. Systematic interventions that focus on to developmentally appropriate play goals and child-oriented play behaviours are necessary to increase the play skills of children with disabilities (Lenakakis et al., 2018; Movahedazarhouligh, 2018).

According to mothers, the relationship between children's play skill levels and toy selection according to toy type was examined and it was determined that there was a significant difference. The 
significance of play skills according to the type of toy highlights both the types of toys sensitive to the special needs of the children, the fact that the child has a toy that the child plays always and the finding that most mothers play games with their children. The variety of toys, which are rich in terms of stimulants offered to children rather than a single toy preference, and spending this playtime together supports the development of children with IR and LD. For it is important to teach these children to play and to play with them. Flexible and multi-environmental play increases the possibility of learning and provides a basis for developing recreational skills in natural environments such as home (Barton \& Wolery, 2008). Children with intellectual disabilities and LD are also supported in developing hand-eye coordination, visual-spatial competencies, and positive behaviour as well as having fun through games (Bedir Eristi et al., 2017).

When all of these are taken into consideration, toys, and planned play activities for children with IR and LR should be designed flexible, appropriate for their level, and especially individualised play activities. It can be said that choosing toys and designing play activities according to the child's characteristics and disability type is effective in achieving high-level gains (Adak Ozdemir \& Ramazan, 2012; Bass \& Mulick, 2007; Metin et al., 1999; Ozyurek \& Akca, 2015).

In other studies, conducted in the field, educational computer games were used for children with IR, and it was figured out that their psychomotor skills improved (Karaca Ciftci \& Aydin, 2017). In his study with autistic children, Er (2018) concluded that the educational play program had a positive effect on the basic motor skills and quality of life of these children. Similarly, in the study conducted by Ayan et al. (2012), it was found out that although children with special educational needs exhibit a passive attitude towards games and toys, they make preferences close to their peers with typical development with the correct guidance. The aforementioned studies and the findings obtained from the current study emphasise the contribution of special children's play skills and toy diversity to the development of children.

The findings of the study are limited to its participants and the context in which it was conducted. In this sense, the study is limited to Konya and with the mothers of children with IR and LR. Accordingly, the inclusion of all areas of special education can create a richer data source for further research. Experimental educational studies can be organised with parents to determine the effect of play on learning. Studies on different categories of toys such as the ability to play with the functions of toys and symbolic play skills can also be carried out.

\section{Ethical statement}

The study data were obtained from mothers who volunteered to participate in the study. The data presented in the study are in accordance with academic and ethical rules. All evaluations and results are presented in accordance with scientific ethics and moral rules.

\section{Acknowledgements}

We would like to thank the mothers who participated in the study, supported, and provided the data voluntarily. We also thank the reviewers who took their time to share their constructive comments.

\section{Funding}

This research did not receive any specific grant from funding agencies in the public, commercial, or not-for-profit sectors.

\section{Conflict of interest}

The authors declare that they have no conflict of interest. 
Konuk Er, R., \& ilik, Ş. (2022). Play skill levels and toy preferences of disabled children according to their mothers. Cypriot Journal of Educational Science. 17(2), 384-395 https://doi.org/10.18844/cjes.v17i2.6821

\section{References}

Adak Ozdemir, A., \& Ramazan, O. (2012). Child, mother and teacher attitudes towards toys. Journal of Educational Sciences Research, 2(1), 1-16. Retrieved from https://dergipark.org.tr/tr/pub/ebader/issue/44650/554611

Alotibi, A., \& Algahtani, F. (2019). The impact of play on life quality of children with intellectual disability. International Journal of Recent Research in Social Sciences and Humanities (IJRRSSH), 6(4), 84-91. Available at: www.paperpublications.org

Aral, N., Gursoy, F., \& Koksal, A. (2001). Game in preschool education. YA-PA published.

Avci, N. (2002). Child and toy. Abece Education and Ekin Journal, 190, 12-14.

Ayan, S., Memis, U. A., Eynur, B. R., \& Kabakcl, A. (2012). The importance of toy and play for children with special needs. International Refereed Academic Journal of Sports Health and Medical Sciences, 2(4), 80-89. https://www.sstbdergisi.com/index.php?sayfa=dergiayrinti\&baslik=ozel-egitime-ihtiyac-duyancocuklarda-oyuncak-ve-oyunun-onemi\&no=40

Aydin Yesilyurt, G. (2019). Child-centered play therapy in children with specific learning difficulties; Effect on perceived parental attitudes, anxiety and academic achievement (Unpublished Master Thesis). Maltepe University Institute of Social Sciences.

Aykara, A. (2017). The importance of childbased play therapy in social work practice with children with disability. Community and Social Work, 28(1), 169-186.

Barton, E. E., \& Wolery, M. (2008). Teaching pretend play to children with disabilities: A review of the literature. Topics in Early Childhood Special Education, 28, 105-112.

Bass, J. D., \& Mulick, J. A. (2007). Social play skill enhancement of children with autism using peers and siblings as therapists. Psychology in the Schools, 44(7), 727-735. https://doi.org/10.1002/ pits.20261

Bedir Eristi, S. D., Firat, M., Izmirli, S., \& Ceylan, B. (2017). Design based instructional game development for children with autism spectrum disorder. Journal of Uludag University Faculty of Education, 30(1), 73-99. https://doi.org/10.19171/uefad.323387

Bekmezci, H., \& Ozkan, H. (2015). The effect of games and toys on children's health. Izmir Dr. Journal of Behcet Uz Children's Hospital, 5(2), 81-87. https://doi.org/10.5222/buchd.2015.081

Besio, S. (2018). Supporting play for the sake of play in children with disabilities, today's children tomorrow's parents an interdisciplinary journal special issue 'play and children with disabilities. Interdisciplinary perspectives'. West University. https://www.ludi-network

Bianquin, N. (2018). The right to play: A powerful promise made also to children with disabilities, today's children tomorrow's parents an interdisciplinary journal special issue 'play and children with disabilities. Interdisciplinary perspectives. West University. https://www.ludi-network

Brodin, J. (1999). Play in children with severe multiple disabilities: Play with toys - A review. International Journal of Disability Development and Education, 46(1), 25-34.

Bulgarelli, D. (2020). Inclusive play and disability in early childhood education and care services. The experiences of Italian practitioners'. In D. Bulgarelli (Ed.), Perspectives and research on play for children with disabilities collected papers. De Gruyter Poland Ltd.

Butgel Tunali, S., Gozu, O., \& Ozen, G. (2016). Using a combination of qualitative and quaniitative methods 'mixed research method'. Anadolu University Faculty of Communication Sciences International Refereed Journal, 24(2), 106-112.

Buysse, V., Goldman, B. D., \& Skinner, M. L. (2002). Setting effects on friendship formation among young children with and without disabilities. Exceptional Children, 68(4), 503-517. https://doi.org/10.1177/001440290206800406

Buyukozturk, S. (2005). Handbook of data analysis for the social sciences (5th ed.). Pegem A Publishing.

Cakmak, A., \& Elibol, F. (2015). Child and game. Visa Publishing. 
Konuk Er, R., \& ilik, Ş. (2022). Play skill levels and toy preferences of disabled children according to their mothers. Cypriot Journal of Educational Science. 17(2), 384-395 https://doi.org/10.18844/cjes.v17i2.6821

Case-Smith, J., \& Kuhaneck, H. M. (2008). Play preferences of typically developing children and children with developmental delays between ages 3 and 7 years. OTJR: Occupation, Participation and Health, 28(1), 1929.

Creswell, J. W., Plano Clark, V. L., Gutmann, M. L., \& Hanson, W. E. (2003). Advanced mixed methods research designs. In A. Tashakkori, \& C. Teddlie (Eds.), Handbook of mixed methods in social and behavioral research (pp. 209-240). Sage Publication.

Coolican, H. (1992). Research methods and statistics in psychology. Hodder \& Stougtton.

Demirci, N., \& Toptas Demirci, P. (2016). Evaluation of gross and motor skills of children with special learning difficulties. Inonu University Journal of Physical Education and Sport Sciences, 3(1), 47-57.

Er, O. (2018). Investigation of the relationship between movement education and educational game and quality of life in children with autism (Unpublished Master's Thesis). Hitit University Institute of Health Sciences.

Eren, B. (2018). Metaphorical perceptions of special education teacher candidates regarding the concept of 'game'. Turkish Studies, 13(18), 569-588. http://dx.doi.org/10.7827/TurkishStudies.14011

Fazlioglu, Y., Ilgaz, G., \& Papatga, E. (2013). The study for validity and reliability of the evaluation of Game Skills Scale. Trakya University Journal of Social Sciences, 15(1), 239-250.

Karaca Ciftci, E., \& Aydin, D. (2017). Disabled children and play. Turkey Clinics Journal of Pediatric Nursing-Special Topics, 3(3),176-184.

Kim, A., Vaughn, S., Elbaum, B., Hughes, M.T., Morris Sloan, C.V., \& Sridhar, D. (2003). Effects of toys or group composition for children with disabilities: A synthesis. Journal of Early Intervention, 25(3), 189-205.

Lenakakis, A., Howard, J. L., \& Felekidou, K. (2018). Play and inclusive education: Greek teachers' attitudes. European Journal of Special Education Research, 3(3), 129-163.

Mahoney, G., Kaiser, A. P., Girolametto, L., MacDonald, J., Robinson, C., Safford, P., \& Spiker, D. (1999). Parent education in early intervention: A call for a renewed focus. Topics in Early Childhood, Special Education, $19,131-140$.

Metin, N., Sahin, S., \& Sanli, E. (1999). Examination of the play corners preferred and the types of plays played by mentally handicapped children at the pre-school level and in the four-nine age group. Journal of Special Education, 2(3), 14-24.

Milli Egitim Bakanligi (2014). Child development and education game activities in special education, Ankara. Access address: http://ismek.ibb.gov.tr/ismek-el-sanatlarikurslari/webedition/file/2016_hbo_program_modulleri/ozelegitimdeoyunetkinlikleri.pdf

Movahedazarhouligh, S. (2018). teaching play skills to children with disabilities: Research-based interventions and practices. Early Childhood Education Journal, 46(6), 587-599.

Nelson, C., McDonnell, A. P., Johnston, S. S., Crompton, A., \& Nelson, A. R. (2007). Keys to play: A strategy to increase the social interactions of young children with autism and their typically developing peers. Education and Training in Developmental Disabilities, 42(2), 165-181.

Ozturk, A. (2010). Game in preschool education. Egiten Published.

Ozyurek, A., \& Akca, F. (2015). An examination of the toy profiles of the children with mental deficiency. Bartin University Journal of the Faculty of Education, 4(2), 516-529.

Papacek, A. M., Chai, Z., \& Green, K. B. (2016). Play and social interaction strategies for young children with autism spectrum disorder in inclusive preschool settings. Young Exceptional Children, 20(10), 1-15.

Pistav Akmese, P., \& Kayhan, N. (2017). An investigation of the self-efficacy levels of the special education teachers regarding game teaching. Ankara University Faculty of Educational Sciences Journal of Special Education, 18, 1-26.

Pouya, S., Demir, S., \& Demirel, O. (2017). Orienteering games for disabled children. Kastamonu University Journal of Forestry Faculty, 17(4), 608-618.

Sezgin, S. (2016, May 5-8). Human and the game: Past, present, and future of games. VIII. International Congressof Educational Research. Canakkale Eighteen March University. 
Stagnitti, K. (2014). 'The parent learn to play program', (pp. 150-159). In E. Prendiville, \& J. Howard, (Eds.). Play Therapy Today-contemporary practice individuals, groups and carers, Routledge.

Stillianesis, S., Spencer, G., Villeneuve, M., Sterman, J., Bundy, A., Wyver, S. Tranter, P., Naughton, G., Ragen, J., \& Beetham, K. S. (2021). Parents' perspectives on managing risk in play for children with developmental disabilities. Disability \& Society. http://doi.org/10.1080/09687599.2021.1874298

Tsai, T. W., \& Lin, M. Y. (2011, September 7-9). An application of interactive game for facial expression of the autisms (pp. 204-211). The Proceeding of 6th International Conference on E-learning and Games (Edutainment 2011)- Edutainment Technologies, Educational Games and Virtual Reality/Augmented Reality Applications.

Tugrul, B. (2015). The power of the game (pp. 209-230). In A. Belgin Aksoy (Ed.). Game in preschool education. Target Publishing.

Venuti, P, Falco, S., Esposito, G., \& Bornstein, M. H. (2009). Mother-child play in children with Down syndrome and typical development. American Journal on Intellectual and Development Disabilities, 114 (4): 274-288. http://doi.org/10.1352/1944-7558-114.4:274-288.

Wong, C., \& Kasari, C. (2012). Play and joint attention of children with autism in the preschool special education classroom. Journal of Autism and Developmental Disorders, 42, 2152-2216.

Yalcinkaya, T. (2005). A few materials used in toy making and toy making (pp. 483-489). In M. Sevinc (Ed.), New approaches in early childhood development and education. Morpa Publishing.

Yaman, D. (2019). Teachers' views on the effect of play on the social development of children with special needs (Unpublished Master Thesis). Near East University Institute of Educational Sciences.

Yikmis, A., Terzioglu, N. K., Kot, M., \& Aktas, B. (2017). The situation of special education teachers' use of games and songs in lessons. Abant Izzet Baysal University Journal of the Faculty of Education, 17(3), 1548-1583.

Yildirim, A., \& Simsek, H. (2005). Qualitative research methods in the social sciences. Seckin Publishing.

Zaatar, W. M. A. (2003). The effectiveness of a recreational program to modify some aspects of the unconscious behavior of mentally retarded children who are able to learn (PhD thesis). Faculty of Education, Ain Shams University. 